\title{
Abstract knowledge of emphatic reduplication in Turkish
}

\author{
Y1lmaz Köylü*
}

\begin{abstract}
This study investigated whether native speakers of Turkish have abstract knowledge regarding the principles guiding the selection of appropriate reduplicative forms in emphatic reduplication in Turkish. 14 native speakers of Turkish completed the study. The participants were asked to reduplicate 48 non-words in 4 experimental conditions where the number of segments and the phonological features of the word forms were manipulated. The 4 experimental conditions had VCV (e.g. /uka/), CVC (e.g. /lot/), CVCV (e.g. /gezi/), and VCCV (e.g./ohfa/) sequences. Each condition included 12 items. In each of the CVC, CVCV, and VCCV conditions, the base forms for 6 items did not include consonants used productively as interpolated consonants $\{\mathrm{p}, \mathrm{m}, \mathrm{s}\}$. The next 6 conditions included $\{\mathrm{p}, \mathrm{m}, \mathrm{s}\}$ either as the first, or the second consonant in the base form of the non-word. The results indicated that the interpolated consonant in Turkish was taken from the set of $\{\mathrm{p}, \mathrm{m}, \mathrm{s}\}$. Moreover, the interpolated consonant was sometimes identical to the second consonant of the base, but never to the first consonant. The most frequently produced interpolated consonant was $\{\mathrm{p}\}$. In the VCV, and VCCV conditions, $\{\mathrm{m}\}$ was preferred over $\{\mathrm{s}\}$. In the CVC, and CVCV conditions, $\{\mathrm{s}\}$ was preferred over $\{\mathrm{m}\}$. The results demonstrate that Turkish native speakers were able to extend the reduplication strategies they employed in real words to non-words.
\end{abstract}

Keywords. Emphatic reduplication; partial reduplication; interpolated consonants; linking consonants; linkers; Turkish.

1. Introduction. In Turkish, it is possible to create emphatic adjectives or adverbs by prefixing a reduplicated (C)VC syllable to the word being made emphatic (Göksel \& Kerslake 2005, Kornfilt 1997). When the adjective or adverb starts with a CV sequence, the reduplicated prefix manifests itself in a CVC form, illustrated in (1). On the other hand, when the adjective or adverb starts with a vowel, the reduplicated prefix takes the form of $\mathrm{VC}$, illustrated in (2). The initial CV or $\mathrm{V}$ segments in such emphatic constructions are identical to the word initial CV or $\mathrm{V}$.

However, as illustrated in (1) and (2), the final $\mathrm{C}$ segment is selected from a set of $\{\mathrm{m}, \mathrm{p}, \mathrm{r}, \mathrm{s}\}$ and it can also show variation since more than one consonant can be used for most adjectives.

(1) Words with an initial CV have a CVC prefix
a. jefil
$\rightarrow$ jemjefil
(green $\rightarrow$ completely green)
b. saru
$\rightarrow$ sapsaru
(yellow $\rightarrow$ completely yellow)
c. temiz $\rightarrow$ tertemiz
(clean $\rightarrow$ completely clean/spotless)
d. katu
kaskatu
(hard $\rightarrow$ extremely hard)

(2) Words with an initial V have a VC prefix
a. $\varepsilon s k i$
$\rightarrow \quad$ epeski
$($ old $\rightarrow$ very old $)$
b. akullu
apakullu
(clever $\rightarrow$ very clever)

\footnotetext{
* I would like to thank Case Western Reserve University, College of Arts and Sciences for their generous travel funds to the $5^{\text {th }}$ workshop on Turkic and languages in contact with Turkic $(\mathrm{Tu}+5)$, where an earlier version of this paper was presented. Special thanks to the audience at $\mathrm{Tu}+5$ for their insightful comments and suggestions. Author: Yılmaz Köylü, The Hong Kong University of Science and Technology (lcyilmaz@ust.hk)

(c) 2020 Author(s). Published by the LSA with permission of the author(s) under a CC BY 4.0 license.
} 
Based on the examples, the emphatic reduplication has been formalized as follows (Kim 2009). (3) Consonant-initial words: $\quad \mathrm{C}_{1} \mathrm{~V}_{1} \mathrm{C}_{2} \ldots \quad \rightarrow \quad \mathrm{C}_{1} \mathrm{~V}_{1}+\{\mathrm{m}, \mathrm{p}, \mathrm{r}, \mathrm{s}\}+$ original form (4) Vowel-initial words: $\quad \mathrm{V}_{1} \mathrm{C}_{1} \ldots \quad \rightarrow \quad \mathrm{V}_{1}+\{\mathrm{m}, \mathrm{p}, \mathrm{r}, \mathrm{s}\} \quad+$ original form

As observed in the data and the rules above, the main issue is to determine the last segment of the prefixed syllable since the first $(\mathrm{V})$ or the first two $(\mathrm{CV})$ segments in reduplication is/are always identical to the first segment/s of the original word. Another issue is to decide whether the final C, also referred to as the linker, or the interpolated consonant in the literature (Yu 1999, Wedel 1999), can show variation.

2. Previous research. There are three approaches towards emphatic or partial reduplication in Turkish. According to lexical approaches, the choice of the linker is lexically determined, and it cannot be predicted depending on the base. To illustrate, Lewis (1967), Underhill (1976), and Dobrovolsky (1987) argue that the interpolated consonant is random and must be learned for each lexical item. Yet, native speakers use interpolated consonants for words they have never heard before with great ease, suggesting that this hypothesis is not plausible. Phonological approaches maintain that the choice of the linker is based on phonological constraints (Demircan 1987, Kelepir 2001). To illustrate, Demircan (1987) states that the interpolated consonant is subject to various dissimilation constraints. He maintains that the underlying form for the interpolated consonant is $-p$ and depending on context, it is replaced by $\{\mathrm{m}, \mathrm{r}, \mathrm{s}$,$\} in a prioritized$ order. Demircan (1987) administered 2 experiments where participants selected reduplicated forms of adjectives, and non-words in Turkish. The results indicated that Turkish partial reduplication consists of some avoidance strategies. Demircan's (1987) findings are summarized below.

(5) Turkish partial reduplication consists of some avoidance strategies:

(i) avoiding the identity between the linker and any consonant that appear in the base,

(ii) avoiding the similarity between the linker and the first $\mathrm{C}$ of a $\mathrm{C}$-initial base,

(iii) avoiding the similarity between the linker and the second $\mathrm{C}$ of a $\mathrm{C}$-initial base,

(iv) avoiding homorganic sequences like -pb-,-st $\int$ - at the morpheme boundary.

Another phonological approach is by Taneri (1990), who collected data from 32 native speakers regarding the reduplicated forms of about 300 Turkish adjectives and adverbs. The results indicated that there was a hierarchy in the choice of the linkers or interpolated consonants. Taneri (1990) concluded that the hierarchy was: $[\mathrm{p}]>[\mathrm{s}]>[\mathrm{m}]>[\mathrm{r}]$ based on the frequency of occurrence. Similar to Demircan (1987), Taneri (1990) also argued that partial reduplication in Turkish is a dissimilative process of a linker with respect to the consonants in the base $\left(\mathrm{C}_{1}\right.$ and $\mathrm{C}_{2}$ ). A final phonological approach is by Kelepir (2001), who proposed certain constrains within the Optimality Theory framework. According to Kelepir (2001), the following constraints interact with each other to give rise to the surface forms observed in interpolated consonants in Turkish.

(6) Kelepir's (2001) Optimality Theoretical analysis:

a. *Repeat [strident]: Don't have the strident linker [s] if there is a strident in the whole base.

b. *-pb-: Don't have the linker [p] with [b]-initial bases.

c. *lab-lab (adjacent): Don't have a [labial][labial] sequence at the reduplication boundary.

d. * $\alpha \mathrm{CONT} \sim \alpha \mathrm{CONT}$ : Don't have a linker that corresponds with the second consonant of the base in terms of continuancy. 
e. ${ }^{*} \mathrm{COR} \sim \mathrm{COR}$ : Don't have the coronal linker $[\mathrm{r}]$ and $[\mathrm{s}]$ if the second consonant of the base is coronal.

f. *LAB LAB: Don't have the labial linker $[\mathrm{p}]$ and $[\mathrm{m}]$ if the second consonant of the base is labial.

g. ${ }^{*} \alpha \mathrm{SON} \sim \alpha \mathrm{SON}$ : Don't have a linker that corresponds with the second consonant of the base in terms of sonority.

Kelepir's (2001) account, however, has received some criticism as her constraints cannot account for certain reduplicated words in Turkish. To illustrate, according to Demir (2018), Kelepir's (2001) constraints cannot capture the attested reduplicated form kos.kodza since it violates the highest ranked constraint * Repeat [strident]. This is shown in the table below.

\begin{tabular}{|c|c|c|c|c|}
\hline$/$ RED+kodza/ & $*$ Repeat [strident] & $* \alpha \mathrm{CONT} \sim \alpha \mathrm{CONT}$ & $* \mathrm{COR} \sim \mathrm{COR}$ & $* \alpha \mathrm{SON} \sim \alpha \mathrm{SON}$ \\
\hline \hline kop.kodza & & $* !$ & & $*$ \\
\hline$\approx$ kos.kodza & $* !$ & & $*$ & $*$ \\
\hline kom.kodza & & $* !$ & $* !$ & \\
\hline & & & \\
\hline
\end{tabular}

Table 1: Derivation of kodza (Demir, 2018)

According to Demir (2018), Kelepir's (2001) analysis is inadequate as it cannot account for 24 $(27 \%)$ words out of 89 consonant initial reduplicated forms in Turkish in her study.

Finally, according to mixed analyses, the linker [r] is lexicalized but the choice of $[\mathrm{p}, \mathrm{s}, \mathrm{m}]$ is determined by phonological constraints (Wedel 1999). Wedel (1999) maintains that Turkish reduplication is a highly productive phenomenon since, when given a new word or even a nonword, native speakers choose one or two of the four consonants with confidence. Wedel (1999) argues that the following constraints interact with each other and give rise to the surface forms in interpolated consonants in Turkish.

(7) a. The interpolated consonant is taken from the set $\{\mathrm{p}, \mathrm{m}, \mathrm{s}\}$,

b. [p] is not selected if $\mathrm{C}_{1}$ is labial,

c. The interpolated consonant must be non-identical to both $\mathrm{C}_{1}$ and $\mathrm{C}_{2}$ of the base,

d. Except where contravened by (7b) and (7c), [p] is selected over [m] or [s].

As Wedel (1999) argues, although the interpolated consonant set includes $\{\mathrm{m}, \mathrm{p}, \mathrm{r}, \mathrm{s}\},[\mathrm{r}]$ is highly restricted and not productive since native speakers are reluctant to employ it when confronted with novel or non-words. Wedel (1999) also maintains that the interpolated consonant cannot be a $[\mathrm{p}]$ if the first consonant in the original word is labial. This is illustrated below.

$$
\text { bejaz } \rightarrow \text { bembejaz but not } \rightarrow \quad \text { *bepbejaz }
$$

Another constraint is that the interpolated consonant cannot be identical to the first or the second consonant of the base, exemplified in (9) and (10) respectively.

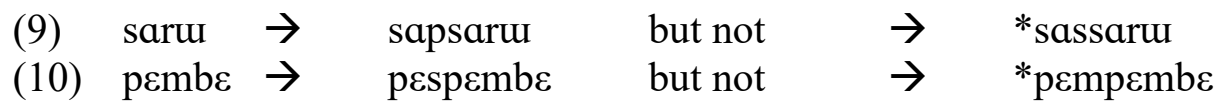

Finally, Wedel (1999) argues that except where violated by (7b) and (7c) above, [p] is selected as the interpolated consonant over [m] or [s]. This generalization finds support given many 
adjectives that start with a vowel that have a [p] as the interpolated consonant (Yu 1999). This is exemplified below.

$$
\text { eski } \rightarrow \quad \text { epeski } \quad \text { but not } \rightarrow \quad *_{\varepsilon m \varepsilon s k i} / *^{*} \varepsilon s s k i
$$

The last generalization also finds support in Demircan (1987), Taneri (1990), and Kelepir (2001), who reported that the preference order of interpolated consonants is $[\mathrm{p}]>[\mathrm{s}]>[\mathrm{m}]>[\mathrm{r}]$. Similarly, Hatiboğlu (1973) reported 121 instances of reduplicated adjectives in the Turkish Electronic Living Lexicon corpus (TELL). The breakdown of the interpolated consonants is given below.

\begin{tabular}{ccccc} 
Interpolated consonant & $\mathrm{m}$ & $\mathrm{p}$ & $\mathrm{r}$ & $\mathrm{s}$ \\
\hline Number of samples & 22 & 55 & 9 & 35 \\
\hline
\end{tabular}

Table 2: The breakdown of interpolated consonants in the TELL corpus

It is also necessary to note that in a number of adjectives and adverbs, the interpolated consonants can show variation as it is possible to reduplicate those words with more than one interpolated consonant. The examples below illustrate the different interpolated consonants for three adjectives. ${ }^{1}$

\begin{tabular}{ccccc}
$\begin{array}{c}\text { Turkish } \\
\text { orthography }\end{array}$ & IPA & Gloss & $\begin{array}{c}\text { Interpolated } \\
\text { consonant/s }\end{array}$ & Reduplicated surface form/s \\
\hline siyah & sijah & black & $\mathrm{m} / \mathrm{p}$ & [simsijah] / [sipsijah] \\
\hline kat1 & katum & solid & $\mathrm{p} / \mathrm{s}$ & [kapkatu] / [kaskatu] \\
\hline yuvarlak & juvarlak & round & $\mathrm{m} / \mathrm{p} / \mathrm{s}$ & $\begin{array}{c}\text { [jumjuvarlak] } / \\
\text { [jupjuvarlak] / [jusjuvarlak] }\end{array}$ \\
\hline
\end{tabular}

Table 3: Variation in interpolated consonants in Turkish emphatic reduplication

Two recent studies on Turkish reduplication are by Tang \& Akkuş (2018), and Demir (2018). In their research, Tang \& Akkuş (2018) start by pointing out a major drawback in earlier studies in Turkish reduplication. By reviewing 10 studies previously carried out on Turkish reduplication, they demonstrate that the judgements of native speakers in those studies were often based on the researchers' intuitions only as the researchers employed forced-choice tasks where the participants had to select a pre-determined linker. To remedy this problem, Tang \& Akkuş (2018) carried out a comprehensive analysis of Turkish partial reduplication with 162 real words where the participants were asked to rate the naturalness of each of the 4 reduplicated forms per item on a scale from 1 to 7 , as well as to pick one option out of the 4 reduplicated forms. The results indicated that it is not just the first or the second consonant, but the subsequent consonants in the base that influence the choice of the linker. In other words, Tang \& Akkuş (2018) maintain that the Obligatory Contour Principle (OCP) effect extends all the way from $\mathrm{C}_{1}$ to $\mathrm{C}_{4}$. Moreover, the authors demonstrated that the OCP constraints are more graded than they have been previously proposed as those effects are not weighted linearly from high to low. Another recent study on Turkish emphatic reduplication is by Demir (2018). She carried out two experiments to investigate the same phenomenon. The first experiment asked 125 participants to reduplicate 10 actual, and 34 non-words. The non-words were categorized into vowel and consonant initial non-words. The consonant initial non-words were further subdivided into

\footnotetext{
${ }^{1}$ See Table A1 in the Appendix for a list of 30 words and their reduplicated forms.
} 
labial-initial, strident-initial and other consonant-initial non-words. Similar to Tang \& Akkuş (2018), participants were asked to reduplicate the items in a free-choice task. That is, participants were not provided with any reduplicated forms as it was done in the forced-choice or multiplechoice tasks employed in the previous studies.

The results demonstrated that participants produced predicted linkers in actual words. Nevertheless, there was more variation in non-words. Moreover, participants utilized some novel linkers, other than $[\mathrm{p}],[\mathrm{m}],[\mathrm{s}]$, or $[\mathrm{r}]$, not attested in Turkish. The linkers that participants provided were sometimes a consonant found in the word, including the final consonant in the base. What is more, participants sometimes even omitted linkers altogether. Demir (2018) demonstrated that the preferences for both vowel and consonant initial non-words were $\mathrm{p}>\mathrm{s}>\mathrm{m}$ $>$ r, which substantiates previous research (Hatiboğlu 1973, Demircan 1987, Taneri 1990, and Kelepir 2001). Demir (2018) concluded that emphatic reduplication in Turkish is a productive process. Crucially, she argues that emphatic reduplication is lexicalized for actual words as her second experiment demonstrated that the same linkers predicted for actual words were not extended to similar non-words. Demir (2018) also argues that the distribution of those linkers is influenced by phonology.

3. The current study. This study investigated whether native speakers of Turkish have abstract knowledge regarding the principles guiding the selection of appropriate reduplicative forms in emphatic reduplication in Turkish. Another goal was to test Wedel's (1999) hypotheses experimentally. The research questions addressed in this study are:

(12) a. Do native speakers of Turkish have abstract knowledge regarding the principles guiding the selection of appropriate reduplicative forms in emphatic reduplication in Turkish? That is, can native speakers of Turkish extend their knowledge of emphatic reduplication to non-words?

b. To what extent do native speakers of Turkish follow the constraints outlined in Wedel (1999) in forming reduplicative forms with non-words?

3.1. METHOD. 14 native speakers of Turkish completed the study on Qualtrics, an online platform to conduct surveys. Participation in the study was voluntary and all the participants gave consent to participate in the study. The participants were all living in the US at the time of the study. Two participants were undergraduate students while 12 were graduate students at various universities in the US. The average age of the participants was 29.2.

3.2. PROCEDURE. The participants were simply asked to reduplicate 48 non-words in 4 different experimental conditions in which the number of segments and the phonological features of the word forms were manipulated. Written instructions were provided. ${ }^{2}$ As the instructions included 4 examples of reduplicated adjectives in Turkish, the participants were not given practice items prior to the experimental component. The 4 experimental conditions had VCV (e.g. /uka/), CVC (e.g. /lot/), CVCV (e.g. /gezi/), and VCCV (e.g. /ohfa/) sequences. Each condition included 12 items. In each of the CVC, CVCV, and VCCV conditions, the base forms for 6 items did not include any consonants used productively as interpolated consonants $\{\mathrm{p}, \mathrm{m}$, $\mathrm{s}\}$. The next 6 conditions included $\{\mathrm{p}, \mathrm{m}, \mathrm{s}\}$ either as the first, or the second consonant in the base form of the non-word. ${ }^{3}$

\footnotetext{
${ }^{2}$ See Table A2 for instructions in Turkish and English.

${ }^{3}$ See Table A3 for the experimental items used to elicit reduplicated forms in Turkish.
} 
3.3. RESULTS. The results indicated that, in line with the predictions of Wedel (1999), native speakers of Turkish produced $\{\mathrm{p}\}$ more than $\{\mathrm{m}\}$, and $\{\mathrm{s}\}$ in the $\operatorname{VCV}$ condition $(68,20$, and 12 percent respectively). This is illustrated below.

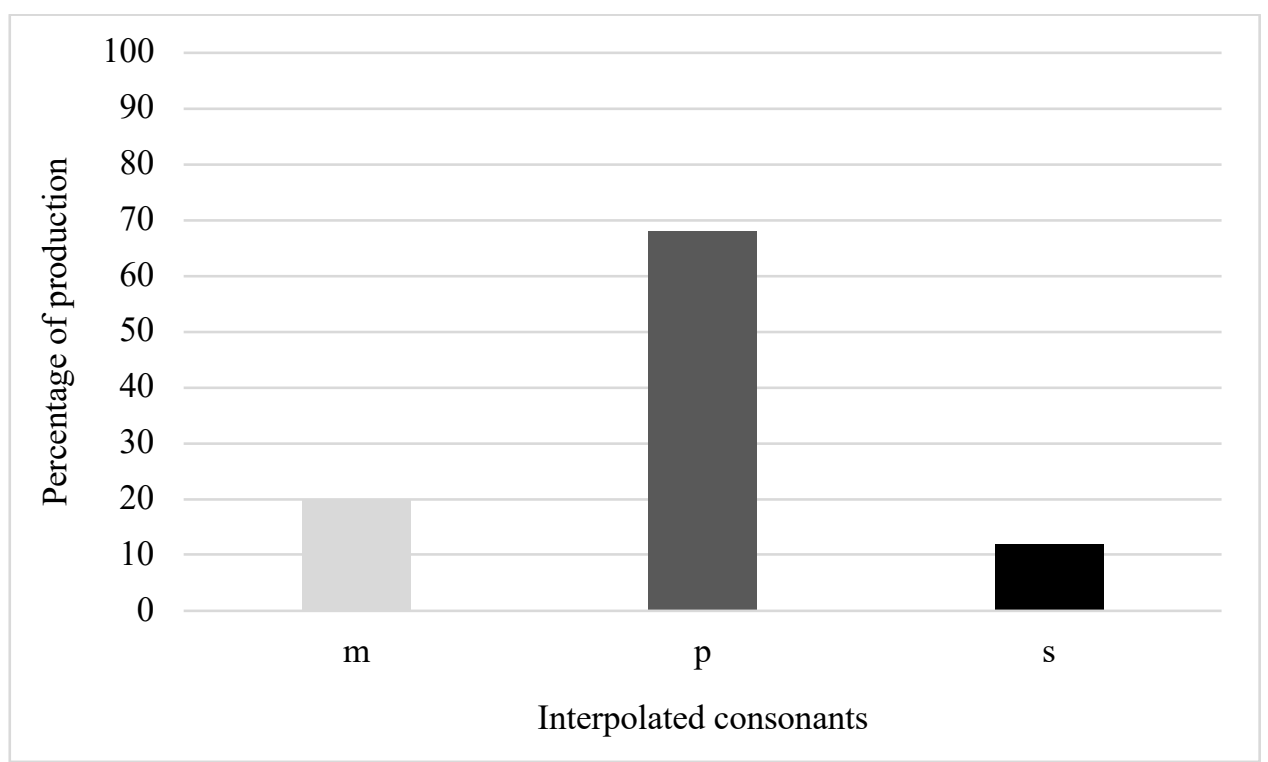

Figure 1. The percentage of interpolated consonants produced in VCV sequences in Turkish The results from the other three conditions are shown in the figures below. Note that in each of the figures below, whenever one of the $\{\mathrm{p}, \mathrm{m}, \mathrm{s}\}$ segments is in the base, that is indicated. In terms of the combined average production in the CVC condition, $\{\mathrm{p}\}$ was selected most frequently $(40.14 \%)$, followed by $\{\mathrm{s}\}$ and $\{\mathrm{m}\}$ (34\%, and $25.85 \%$ respectively). As hypothesized by Wedel (1999), the interpolated consonant was never identical to $C_{1}$ or $C_{2}$ of the base.

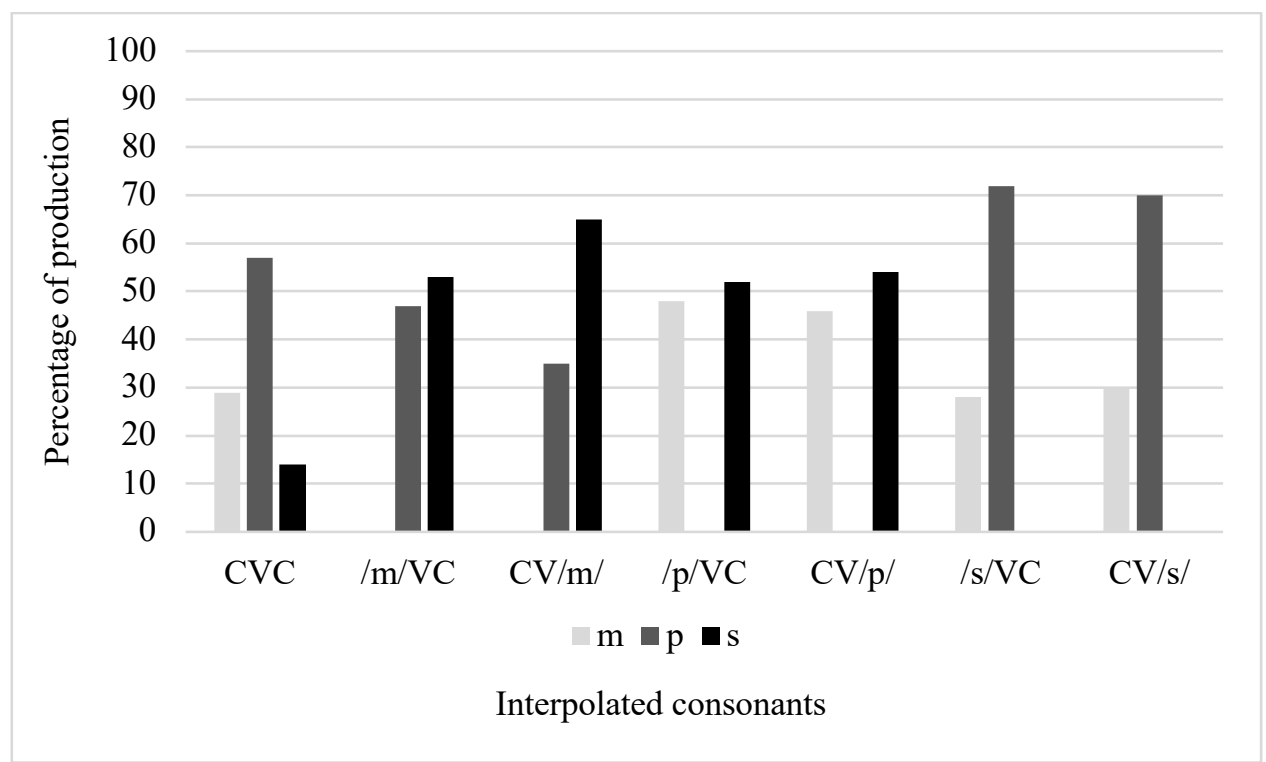

Figure 2. The percentage of interpolated consonants produced in CVC sequences in Turkish With respect to the combined average production, the CVCV condition demonstrated that $\{\mathrm{p}\}$ was selected most frequently (47.42\%), followed by $\{\mathrm{s}\}$ and $\{\mathrm{m}\}(29.57 \%$, and $23 \%$ 
respectively). The interpolated consonant was sometimes identical to $\mathrm{C}_{2}$ of the base. This provides counterargument against Wedel (1999), who maintains that the interpolated consonant can never be identical to $\mathrm{C}_{1}$ or $\mathrm{C}_{2}$ of the base.

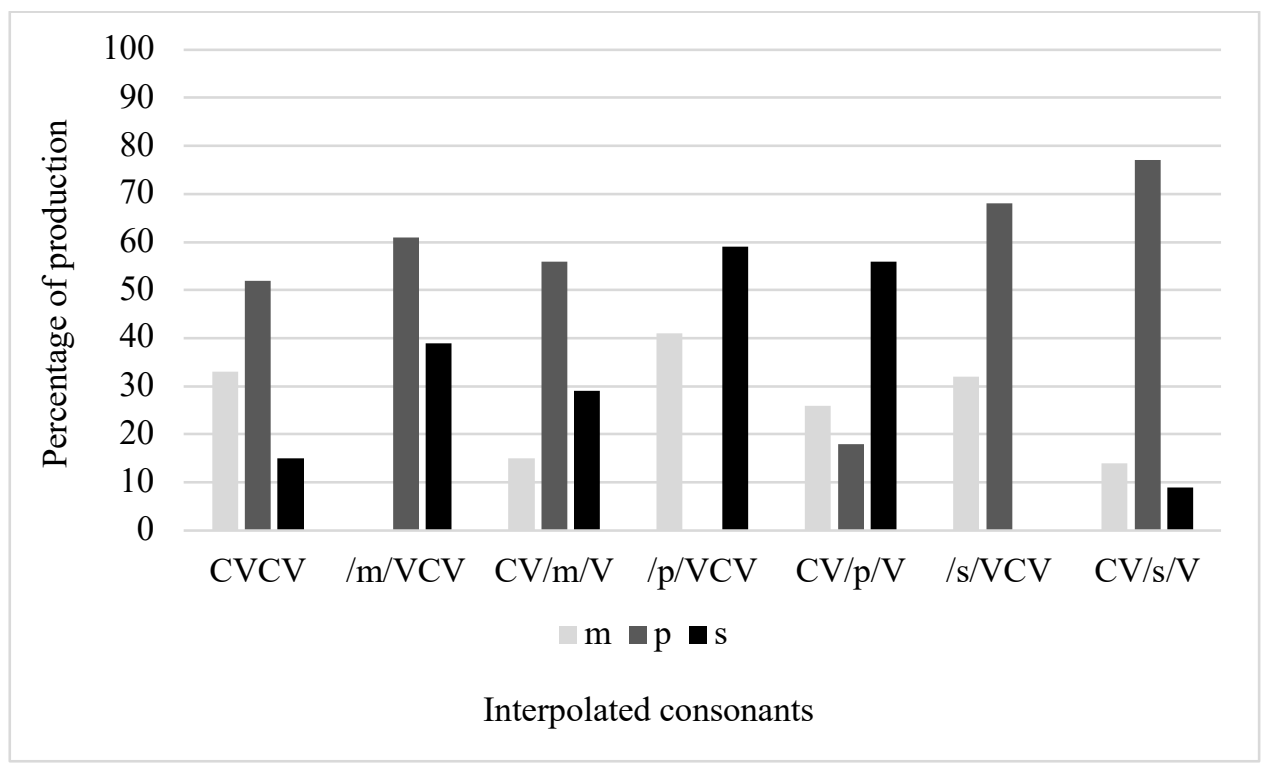

Figure 3. The percentage of interpolated consonants produced in CVCV sequences in Turkish In regard to the combined average production, the VCCV condition indicated that $\{\mathrm{p}\}$ was selected most frequently (49.14\%), followed by $\{\mathrm{m}\}$ and $\{\mathrm{s}\}(26.71 \%$, and $24.14 \%)$. The interpolated consonant was sometimes identical to $\mathrm{C}_{2}$ of the base, but never to $\mathrm{C}_{1}$.

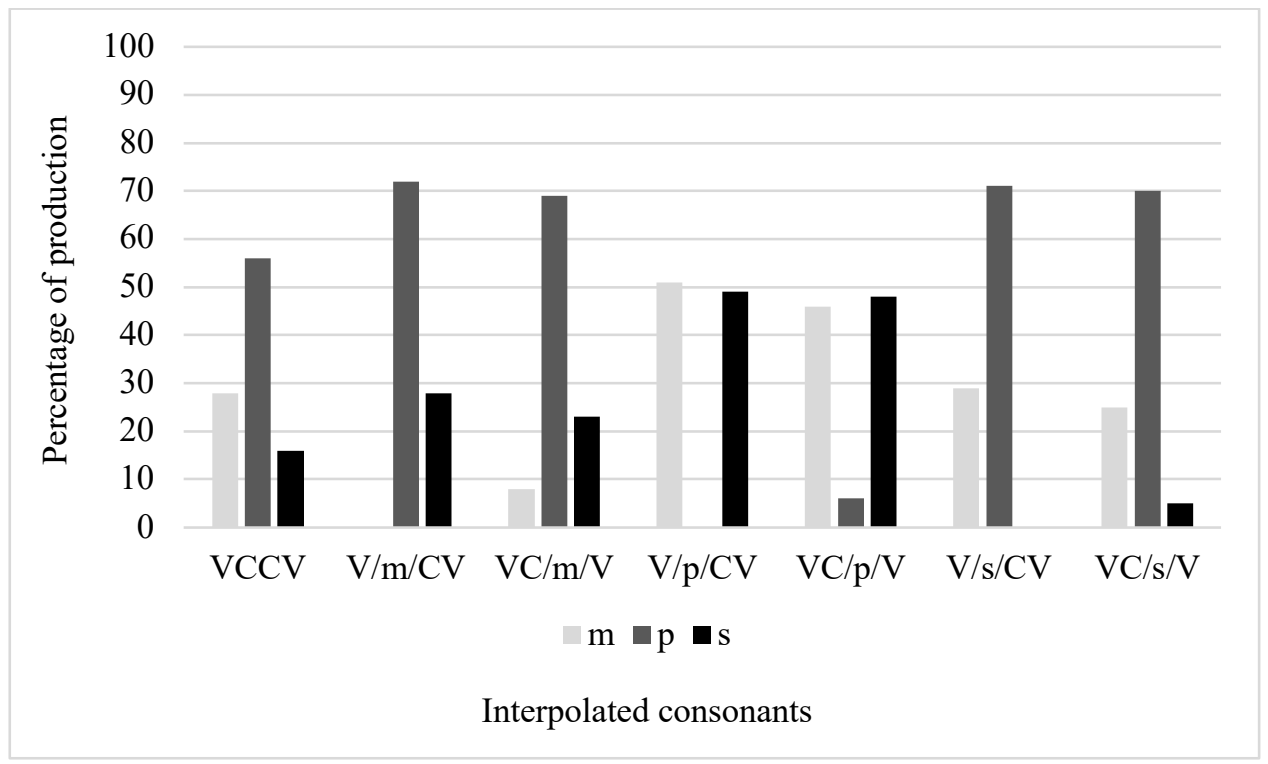

Figure 4. The percentage of interpolated consonants produced in VCCV sequences in Turkish

4. Conclusion. The results demonstrate that Turkish emphatic reduplication is a productive process and native speakers do have abstract knowledge of emphatic reduplication. The interpolated consonant in Turkish is indeed taken from the set of $\{\mathrm{p}, \mathrm{m}, \mathrm{s}\}$. Contrary to Wedel (1999) and Kelepir (2001), \{p $\}$ was sometimes selected even when $\mathrm{C}_{1}$ was labial (e.g. mok $\rightarrow$ 
mopmok). Moreover, the interpolated consonant was sometimes identical to $\mathrm{C}_{2}$ of the base, but never to $\mathrm{C}_{1}$. The most frequently produced interpolated consonant was $\{\mathrm{p}\}$. In the $\mathrm{VCV}$, and VCCV conditions, $/ \mathrm{m} /$ was preferred over $\{\mathrm{s}\}$. In the CVC, and CVCV conditions, $\{\mathrm{s}\}$ was preferred over $\{\mathrm{m}\}$.

This study confirms the significance of experimental data, particularly productive measures such as writing (Demir 2018) or orally producing an emphatic form to investigate emphatic reduplication in Turkish.

5. Implications and future directions. The Turkish facts regarding emphatic reduplication could be accounted for by Yip's (1998) identity avoidance principle, according to which sequences of homophonous phonemes or morphemes are avoided across world's languages. Such avoidance has been attested for many languages in the literature (e.g. in Korean reduplication by An 2012). A similar account is Fromkin's (2000) The Not-Too-Similar Principle, which asserts that similar obstruent sequences are not permitted in English.

As Tang \& Akkuş (2018) illustrated, the significance of all the consonants in the base should be investigated in studies regarding emphatic reduplication in Turkish. Another similar direction would be to research the contribution of vowels. As Demir (2018), illustrated, her participants reduplicated beyaz (white) using a well-attested form in Turkish: /bejaz/ $\rightarrow$ /bembejaz/. Nevertheless, the participants did not extend the same interpolated consonant to a non-word /bojuz/ as they produced various forms such as \{bombojuz, bopbojuz, bosbojuz, borbojuz, bozbojuz . Thus, an interesting question is whether the vowels also have an influence on the choice of the interpolated consonant in emphatic reduplication in Turkish. One way to test such a hypothesis would be to investigate whether front or back vowels lead to any difference in the interpolated consonants when the consonants in the base are the same. Some non-words through which such a hypothesis could be tested are listed in (13).

(13) Sample non-words to test the effect of vowels on the choice of interpolated consonants
a. /telge/ $\rightarrow$ ?
/tałga/
$\rightarrow$ ?
b. /tilgi/ $\rightarrow$ ?
/tuitgu/ $\quad \rightarrow$ ?
c. /tølgø/ $\rightarrow$ ?
/totgo/ $\rightarrow$ ?
d. /tylgy/ $\rightarrow$ ?
/tułgu/
$\rightarrow$ ?

Although I do not know of any studies that have investigated the effect of vowels on the choice of interpolated consonants, I have different judgments as to what those consonants should be in the two sets above with different vowels. Such native speaker intuitions should be experimentally tested with native speakers of Turkish in future research.

\section{References}

An, Young-Ran. 2012. Identity avoidance and speaker preference in Korean. Studies in Phonetics, Phonology and Morphology 3. 397-412.

Demir, Neşe. 2018. Turkish reduplicative adjectives and adverbs. Proceedings of the Linguistic Society of America 3(19). 1-14. https://doi.org/10.3765/plsa.v3i1.4300.

Demircan, Özgür. 1987. Emphatic reduplication in Turkish. In Hendrik Boeschoten \& Ludo Th Verhoeven (eds.), Studies in Modern Turkish: Proceedings of the $3^{\text {rd }}$ Conference on Turkish. 24-41. Tilburg: Tilburg University Press.

Dobrovolsky, Michael. 1987. Why CVC in Turkish reduplication? In Pirkko Lilius \& Mirja Saari (eds.), The Nordic Languages and Modern Linguistics 6. 131-146. Helsinki: Helsinki University Press. 
Fromkin, Victoria A. 2000. Linguistics: An introduction to linguistic theory. Oxford: Blackwell. Göksel, Aslı \& Kerslake, Celia. 2005. Turkish: A comprehensive grammar. New York, NY: Routledge.

Hatiboğlu, Vecihe. 1973. Pekiştirme ve Kuralları. Turk Dil Kurumu.

Kelepir, Meltem. 2001. To be or not to be faithful. In Aslı Göksel \& Celia Kerslake (eds.), Studies on Turkish and Turkic Languages: Proceedings of the 9th International Conference on Turkish Linguistics. 11-18. Wiesbaden: Harrassowitz.

Kim, Hyung-Soo. 2009. The full-to-partial reduction in Korean and Turkish reduplication. Linguistic Research 2. 121-148.

Kornfilt, Jaklin. 1997. Turkish. New York, NY: Routledge.

Lewis, Geoffrey. 1967. Turkish grammar. Oxford: Oxford University Press.

Taneri, Mübeccel. 1990. A type of reduplication in Turkish. Kansas Working Papers in Linguistics 15. 96-132.

Tang, Kevin \& Akkuş, Faruk. 2018. OCP effects in Turkish partial reduplication: Locality and feature specificity. 26th Manchester Phonology Meeting. University of Manchester, UK.

Underhill, Robert. 1976. Turkish Grammar. Cambridge: The MIT Press.

Wedel, Andrew. 1999. Turkish Emphatic Reduplication. Santa Cruz: UCSC MA thesis.

Yavaş, Mehmet. 1980. Borrowing and its implications for Turkish phonology. Lawrence, KS: KU dissertation.

Yip, Moira. 1998. Identity avoidance in phonology and morphology. In Steven G. Lapointe, Diane K. Brentari and Patrick M. Farrell (eds.), Morphology and its relation to phonology and syntax. 216-246. Stanford, CA: CSLI Publications.

Yu, Alan C. L. 1999. Dissimilation and Allomorphy: The Case of Turkish Emphatic Reduplication. Berkeley: UC Berkeley MA thesis. 
Appendix

\begin{tabular}{|c|c|c|c|c|c|c|c|}
\hline & $\begin{array}{c}\text { Turkish } \\
\text { orthography }\end{array}$ & IPA & $\mathrm{C}_{1}$ & $\mathrm{C}_{2}$ & Gloss & $\begin{array}{l}\text { Interpolated } \\
\text { consonant/s }\end{array}$ & $\begin{array}{c}\text { Reduplicated surface } \\
\text { form } / \mathrm{s}\end{array}$ \\
\hline 1 & beyaz & /bejaz/ & $\mathrm{b}$ & $\mathrm{j}$ & white & $\mathrm{m}$ & [bembejaz] \\
\hline 2 & hizli & /huzlu/ & $\mathrm{h}$ & $\mathrm{Z}$ & fast & $\mathrm{p}$ & [huphuzlu] \\
\hline 3 & sessiz & /sessiz/ & $\mathrm{S}$ & $\mathrm{s}$ & silent & $\mathrm{p}$ & [sepsessiz] \\
\hline 4 & sar1 & /saru/ & $\mathrm{S}$ & $\mathrm{r}$ & yellow & $\mathrm{p}$ & [sapsaru] \\
\hline 5 & gürültülü & /gyryltyly/ & $\mathrm{g}$ & $\mathrm{r}$ & loud & $\mathrm{p}$ & [gypypryltyly] \\
\hline 6 & kahverengi & /kahverengi/ & $\mathrm{k}$ & $\mathrm{h}$ & brown & $\mathrm{p}$ & [kapkahverengi] \\
\hline 7 & gri & /gri/ & g & $\mathrm{r}$ & gray & $\mathrm{p}$ & [gupgri] \\
\hline 8 & turuncu & /turundzu/ & $\mathrm{t}$ & $\mathrm{r}$ & orange & $\mathrm{p}$ & [tupturundzu] \\
\hline 9 & k1zil & /kuzul/ & $\mathrm{k}$ & $\mathrm{Z}$ & red & $\mathrm{p}$ & [kupkuzul] \\
\hline 10 & heyecanlı & /hejedzanlu/ & $\mathrm{h}$ & $\mathrm{j}$ & excited & $\mathrm{p}$ & 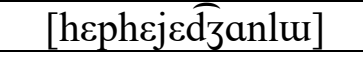 \\
\hline 11 & talihsiz & /talihsiz/ & $\mathrm{t}$ & 1 & unfortunate & $\mathrm{p}$ & [taptalihsiz] \\
\hline 12 & aydınlık & /ajdunluuk/ & $\mathrm{j}$ & $\mathrm{d}$ & bright & $\mathrm{p}$ & [apajdunluk] \\
\hline 13 & eski & /عski/ & $\mathrm{s}$ & $\mathrm{k}$ & old & $\mathrm{p}$ & [epeski] \\
\hline 14 & durgun & /dupdurgun/ & $\mathrm{d}$ & $\mathrm{r}$ & still & $\mathrm{p}$ & [dupdurgun] \\
\hline 15 & ciddi & dziddi/ & $\widehat{\mathrm{d} 3}$ & $\mathrm{~d}$ & serious & $\mathrm{p}$ & [dzipdziddi] \\
\hline 16 & kirli & /kirli/ & $\mathrm{k}$ & $\mathrm{r}$ & dirty & $\mathrm{p}$ & [kipkirli] \\
\hline 17 & temiz & /temiz/ & $\mathrm{t}$ & $\mathrm{m}$ & clean & $\mathrm{r}$ & [tertemiz] \\
\hline 18 & berbat & berbat/ & $\mathrm{b}$ & $\mathrm{r}$ & terrible & $\mathrm{s}$ & [besberbat] \\
\hline 19 & mavi & /mavi/ & $\mathrm{m}$ & $\mathrm{V}$ & blue & $\mathrm{s}$ & [masmavi] \\
\hline 20 & mor & /mor/ & $\mathrm{m}$ & $\mathrm{r}$ & purple & $\mathrm{s}$ & [mosmor] \\
\hline 21 & pembe & /pembe/ & $\mathrm{p}$ & $\mathrm{m}$ & pink & $\mathrm{s}$ & [pespembe] \\
\hline 22 & siyah & /sijah/ & $\mathrm{S}$ & $\mathrm{j}$ & black & $\mathrm{m} / \mathrm{p}$ & $\begin{array}{l}\text { [simsijah] } \\
\text { [sipsijah] }\end{array}$ \\
\hline 23 & sert & /scrt/ & $\mathrm{s}$ & $\mathrm{r}$ & hard & $\mathrm{m} / \mathrm{p}$ & $\begin{array}{l}\text { [s\&ms\&rt] } \\
{[\mathrm{s} \varepsilon p s \varepsilon r t]}\end{array}$ \\
\hline 24 & kat1 & katu/ & $\mathrm{k}$ & $\mathrm{t}$ & solid & $\mathrm{p} / \mathrm{s}$ & $\begin{array}{l}\text { [kapkatu] } \\
\text { [kaskatu] }\end{array}$ \\
\hline 25 & lacivert & /laḑzivert/ & 1 & $\widehat{\mathrm{d} 3}$ & dark blue & $\mathrm{p} / \mathrm{s}$ & $\begin{array}{l}\text { [laplaḑivert] } \\
\text { [lasla } \overline{d z i v e r t]}\end{array}$ \\
\hline 26 & k1rmız1 & /kurmuzu/ & $\mathrm{k}$ & $\mathrm{r}$ & red & $\mathrm{p} / \mathrm{s}$ & $\begin{array}{l}\text { [kupkurmuzu] } \\
\text { [kuskurmuzu] }\end{array}$ \\
\hline 27 & yumuşak & /jumufak/ & $\mathrm{j}$ & $\mathrm{m}$ & soft & $\mathrm{p} / \mathrm{s}$ & 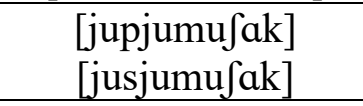 \\
\hline 28 & tatlı & $/$ tatl1/ & $\mathrm{t}$ & $\mathrm{t}$ & sweet & $\mathrm{p} / \mathrm{s}$ & $\begin{array}{l}\text { [taptatlu] } \\
\text { [tastatlu] }\end{array}$ \\
\hline 29 & yuvarlak & /juvarlak/ & $\mathrm{j}$ & $\mathrm{v}$ & round & $\mathrm{m} / \mathrm{p} / \mathrm{s}$ & $\begin{array}{l}\text { [jumjuvarlak] } \\
\text { [jupjuvarlak] } \\
\text { [jusjuvarlak] }\end{array}$ \\
\hline 30 & yeşil & /jعjil/ & $\mathrm{j}$ & $\int$ & green & $\mathrm{m} / \mathrm{p} / \mathrm{s}$ & 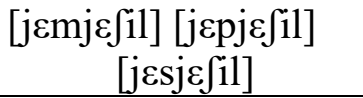 \\
\hline
\end{tabular}

Table A1: Some example words in Turkish emphatic reduplication 


\begin{tabular}{|c|l|}
\hline \multicolumn{1}{|c|}{ Talimatlar } & \multicolumn{1}{c|}{ Instructions } \\
\hline $\begin{array}{l}\text { Türkçede bazı kelimeleri aşağıdaki gibi } \\
\text { pekiştirebiliriz. }\end{array}$ & $\begin{array}{l}\text { In Turkish, we can modify some words as } \\
\text { illustrated below. } \\
\text { akıllı } \rightarrow \text { apakıllı }\end{array}$ \\
yeşil $\rightarrow$ yemyeşil & akıllı $\rightarrow$ apakıllı \\
katı $\rightarrow$ kaskatı & yeşil $\rightarrow$ yemyeşil \\
temiz $\rightarrow$ tertemiz & temiz $\rightarrow$ tertemiz \\
Bu çalışmada anlam ifade etmeyen 48 kelime & In this study, you will see 48 non-words. \\
göreceksiniz. Lütfen bu kelimelerin Türkçe & Please suppose that these are Turkish \\
olduğunu düşünün ve yukarıdaki stratejiyi & words and modify those 48 words using the \\
kullanarak bu 48 kelimeyi pekiştirin. Lütfen & strategy above. Please only write one word. \\
sadece 1 kelime yazın. & \\
\hline
\end{tabular}

Table A2: Instructions in Turkish and English

\begin{tabular}{|c|c|c|c|c|c|c|c|}
\hline Condition & $\begin{array}{l}\text { Word } \\
\text { form }\end{array}$ & $\begin{array}{l}\text { The non- } \\
\text { word in } \\
\text { Turkish } \\
\text { orthography }\end{array}$ & $\begin{array}{l}\text { The non- } \\
\text { word in } \\
\text { IPA }\end{array}$ & Condition & $\begin{array}{l}\text { Word } \\
\text { form }\end{array}$ & $\begin{array}{l}\text { The non- } \\
\text { word in } \\
\text { Turkish } \\
\text { orthography }\end{array}$ & $\begin{array}{l}\text { The non- } \\
\text { word in } \\
\text { IPA }\end{array}$ \\
\hline \multirow{12}{*}{$\begin{array}{c}\text { Condition } \\
1\end{array}$} & \multirow{12}{*}{$\mathrm{VCV}$} & ajo & [azo] & \multirow{12}{*}{$\begin{array}{c}\text { Condition } \\
3\end{array}$} & \multirow{12}{*}{$\mathrm{CVCV}$} & geji & [gezi] \\
\hline & & erü & [عгy] & & & jige & [3ige] \\
\hline & & 1la & [uła] & & & huva & [huva] \\
\hline & & izo & [izo] & & & vahu & [vahu] \\
\hline & & ofu & [ofu] & & & taro & [taro] \\
\hline & & öti & [œti] & & & rato & [rato] \\
\hline & & uke & [uke] & & & miz1 & [muzu] \\
\hline & & üci & [ydzi] & & & Zlm1 & [zumu] \\
\hline & & ane & [anc] & & & Z1p1 & [zupu] \\
\hline & & eka & [Eka] & & & p1Z1 & [puzu] \\
\hline & & 190 & [ugo] & & & soki & [soki] \\
\hline & & ija & [iza] & & & kosi & [kosi] \\
\hline \multirow{12}{*}{$\begin{array}{c}\text { Condition } \\
2\end{array}$} & \multirow{12}{*}{$\mathrm{CVC}$} & hüf & [hyf] & \multirow{12}{*}{$\begin{array}{c}\text { Condition } \\
4\end{array}$} & \multirow{12}{*}{$\mathrm{VCCV}$} & ütlü & [ytly] \\
\hline & & füh & [fyh] & & & ültü & [ylty] \\
\hline & & nul & [nul] & & & akri & [akri] \\
\hline & & lun & [lun] & & & arki & [arki] \\
\hline & & gur & [gur] & & & ohfa & [ohfa] \\
\hline & & rug & [rug] & & & ofha & [ofha] \\
\hline & & mok & [mok] & & & imti & [imti] \\
\hline & & kom & [kom] & & & itmi & [itmi] \\
\hline & & peç & {$[p \varepsilon \widehat{t}]$} & & & apta & [apta] \\
\hline & & çep & {$\left[\mathrm{t} \int \mathrm{sp}\right]$} & & & atpa & [atpa] \\
\hline & & sag & [sag] & & & üsvü & [ysvy] \\
\hline & & gas & [gas] & & & üvsü & [yvsy] \\
\hline
\end{tabular}

Table A3: Experimental items to elicit reduplicated forms in Turkish 